\title{
Amyloid $\beta$ induces neuronal cell death through ROS-mediated ASK1 activation
}

\author{
H Kadowaki ${ }^{1,2,3,8}$, H Nishitoh ${ }^{1,2,3,8}$, F Urano ${ }^{4}$, C Sadamitsu ${ }^{1,2,5}$,

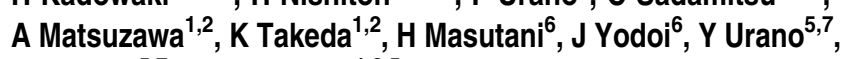 \\ T Nagano ${ }^{5,7}$ and H Ichijo*,1,2,5 \\ 1 Laboratory of Cell Signaling, Graduate School of Pharmaceutical Sciences, \\ University of Tokyo, 7-3-1 Hongo, Bunkyo-ku, Tokyo 113-0033, Japan \\ 2 CREST, Japan Science and Technology Corporation, 7-3-1 Hongo, Bunkyo- \\ ku, Tokyo 113-0033, Japan \\ ${ }^{3}$ Laboratory of Cell Signaling, Graduate School of Tokyo Medical and Dental \\ University, 1-5-45 Yushima, Bunkyo-ku, Tokyo 113-8549, Japan \\ 4 University of Massachusetts Medical School, Program in Gene Function and \\ Expression, 364 Plantation Street, LRB 522, Worcester, MA 01605-2324, USA \\ ${ }^{5}$ Center of Excellence Program, Graduate School of Pharmaceutical Sciences, \\ University of Tokyo, 7-3-1 Hongo, Bunkyo-ku, Tokyo 113-0033, Japan \\ 6 Department of Biological Responses, Institute for Virus Research, Kyoto \\ University, Kyoto 606-8507, Japan \\ 7 Laboratory of Chemistry and Biology, Graduate School of Pharmaceutical \\ Sciences, University of Tokyo, 7-3-1 Hongo, Bunkyo-ku, Tokyo 113-0033, \\ Japan \\ 8 These authors contributed equally to this work \\ * Corresponding author: H Ichijo, Laboratory of Cell Signaling, Graduate School \\ of Pharmaceutical Sciences, University of Tokyo, 7-3-1 Hongo, Bunkyo-ku, \\ Tokyo 113-0033, Japan. Tel: + 8135841 4859; Fax: + 8135841 4778; \\ E-mail: ichijo@mol.f.u-tokyo.ac.jp
}

Received 06.5.04; revised 13.9.04; accepted 20.9.04 Edited by G Melino

\section{Abstract}

Amyloid $\beta(A \beta)$ is a main component of senile plaques in Alzheimer's disease and induces neuronal cell death. Reactive oxygen species (ROS), nitric oxide and endoplasmic reticulum (ER) stress have been implicated in $A \beta$-induced neurotoxicity. We have reported that apoptosis signalregulating kinase 1 (ASK1) is required for ROS- and ER stress-induced JNK activation and apoptosis. Here we show the involvement of ASK1 in A $\beta$-induced neuronal cell death. $A \beta$ activated ASK1 mainly through production of ROS but not through ER stress in cultured neuronal cells. Importantly, $A S K 1^{-1-}$ neurons were defective in A $\beta$-induced JNK activation and cell death. These results indicate that ROS-mediated ASK1 activation is a key mechanism for $A \beta$-induced neurotoxicity, which plays a central role in Alzheimer's disease.

Cell Death and Differentiation (2005) 12, 19-24.

doi:10.1038/sj.cdd.4401528

Keywords: amyloid $\beta$; ASK1; JNK; reactive oxygen species (ROS); neuronal cell death

Abbreviations: $\mathrm{A} \beta$, amyloid $\beta$; ROS, reactive oxygen species; $\mathrm{NO}$, nitric oxide; ER, endoplasmic reticulum; ASK1, apoptosis signal-regulating kinase 1; $A D$, Alzheimer's disease; FAD, familial $A D$; SAD, sporadic AD; APP, amyloid precursor protein; PS, presenilin; NOSs, NO synthases; MAPKKK, mitogen-activated protein kinase kinase kinase; PG, propyl gallate; VitE, vitamin E; hROS, highly reactive oxygen species; MTT, 3'-(4,5-dimethyl-2thiazolyl)-2,5-diphenyl-2H-tetrazolium bromide; GFAP, glial fibrillary acidic protein; HBSS, Hank's balanced salt solution; IP, immunoprecipitation; Tg, thapsigargin; WB, immunoblotting

\section{Introduction}

Alzheimer's disease (AD) is a neurodegenerative disorder clinically characterized by progressive loss of memory. Common pathological features of familial $A D$ (FAD) and sporadic $A D$ (SAD) include senile plaques, neurofibrillary tangles and neuronal loss in brain regions involved in learning and memory. A role of the accumulation of amyloid $\beta(\mathrm{A} \beta)$ peptides in forming fibrillar deposits, a principal component of senile plaques, has been suggested by several findings. ${ }^{1,2} \mathrm{~A} \beta$ peptides are 39-43amino-acid peptides cleaved by $\beta$ - and $\gamma$ secretases from the amyloid precursor protein (APP). ${ }^{3}$ FAD has been linked to mutations in three different genes: the APP gene, presenilin (PS) 1 gene and PS2 gene. Expression of these mutant proteins in cultured cells results in increased production of fibrillar $\mathrm{A} \beta$ peptides. In addition, fibrillar $\mathrm{A} \beta$, but not soluble $\mathrm{A} \beta$, is toxic to cultured neuronal cells. ${ }^{2}$ These findings suggest that aggregation of $\mathrm{A} \beta$ plays an important role in the development of $A D$. Thus, it is important to elucidate the molecular mechanisms of $A \beta$-induced neuronal cell death. Several studies have shown that dying cells display the characteristics of apoptosis in AD brains and in cultures of neurons exposed to $\mathrm{A} \beta{ }^{4}$ It has been reported that $\mathrm{A} \beta$ impairs mitochondrial redox activity and increases the generation of reactive oxygen species (ROS) ${ }^{5-7}$ Several studies also suggest that $A \beta$-induced oxidative stress leads to apoptotic neuronal cell death that can be inhibited by antioxidants. ${ }^{7-9}$ Nitric oxide (NO) synthesized by NO synthases (NOSs) also appears to participate in the pathogenesis of AD. Pathologic studies have suggested a functional link between NO and AD, in that neurofibrillary tangles in $A D$ brain contain inducible NOS and exhibit nitrotyrosine formation in proteins. ${ }^{10,11}$ Induction of neurotoxicity by FAD-linked mutations of PS1 is inhibited by NOS inhibitors. ${ }^{12}$ These findings suggest that ROS and NO may be important mediators of $\mathrm{A} \beta$-induced neuronal cell death in the development of AD. However, the specific target of ROS and/or NO in $A D$ remains to be elucidated.

Accumulation of unfolded proteins within the lumen of the endoplasmic reticulum (ER) induces ER stress, and ER stress has been implicated in neurodegenerative disorders including $\mathrm{AD},{ }^{13}$ Parkinson's disease ${ }^{14}$ and polyglutamine diseases. ${ }^{15}$ We have recently shown that the mammalian mitogenactivated protein kinase kinase kinase (MAPKKK) termed apoptosis signal-regulating kinase 1 (ASK1) constitutes an IRE1-TRAF2-ASK1 cascade that eventually activates JNK in ER stress signaling. ${ }^{15}$ We also demonstrated that primary 
neurons derived from $A S K 1^{-1-}$ mice were resistant to ER stress-induced cell death, and that the ASK1-mediated apoptosis pathway plays an important role in polyglutamine diseases.

$\mathrm{A} \beta$ induces activation of JNK and phosphorylation of CJun. ${ }^{16,17}$ In addition, $A \beta$-induced neuronal cell death is inhibited either by the expression of dominant-negative mutant of c-Jun, by treatment with a JNK inhibitor or by the targeted disruption of C-Jun or JNK3. ${ }^{16-18}$ Nevertheless, the mechanism of $\mathrm{A} \beta$-induced JNK activation is unknown. ASK1 is activated in response to $\mathrm{H}_{2} \mathrm{O}_{2}$, TNF and ER stress through distinct mechanisms. ${ }^{19,20}$ Overexpression of wild-type or activated mutant of ASK1 induces apoptosis in various cells through mitochondria-dependent caspase activation. ${ }^{19,21,22}$ Recently, we showed that ROS-induced sustained activation of JNK is lost in $A S K 1^{-1-}$ MEFs and that $A S K 1^{-1-}$ cells are less susceptible than $A S K 1^{+/+}$cells to ROS. ${ }^{23}$ These observations suggested that ASK1 is a key element in ROSinduced apoptosis.

In the present study, activation of ASK1 through ROS was found to constitute a major signaling pathway for $A \beta$-induced cell death, which plays an important role in the pathogenesis of AD.

\section{Results and discussion}

\section{A $\beta$ activates ASK1-JNK pathway}

The molecular mechanism of $A \beta$-induced neuronal cell death is not well understood. It was previously shown that fibrillar $\mathrm{A} \beta$ activated JNK in cortical neurons ${ }^{16,17}$; however, the molecular mechanism by which $\mathrm{A} \beta$ activates JNK is unknown. Since ASK1 is a MAPKKK that activates the JNK signaling cascade, we examined whether ASK1 is involved in $A \beta$-induced JNK activation. We first examined the effect of $A \beta$ on the catalytic activity of ASK1 by an anti-phospho-ASK1 antibody that monitors activating autophosphorylation of ASK1. ${ }^{24}$ Treatment of PC12 cells with A $\beta$ activated endogenous ASK1 in a dose-dependent manner (Figure 1a). Activation of ASK1 was observed within $4 \mathrm{~h}$ and continued until $16 \mathrm{~h}$ after stimulation with $\mathrm{A} \beta$, in parallel with JNK activation (Figure $1 \mathrm{~b}$ ).

\section{A $\beta$ activates ASK1 independent of the ER stress pathway}

ER stress has been suggested to be involved in the pathogenesis of $A D .^{13,25}$ Since $A S K 1$ is required for ER stress-induced cell death, ${ }^{15} \mathrm{~A} \beta$ might activate the ASK1-JNK pathway through ER stress. We thus examined whether $\mathrm{A} \beta$ induces ER stress as assessed by band-shift analysis of ERresident transmembrane kinases, IRE1 and PERK. IRE1 and PERK were clearly activated by treatment with thapsigargin $(\mathrm{Tg})$, which triggers ER stress by depletion of luminal calcium stores, but not by treatment with $\mathrm{A} \beta$, in PC12 cells (Figure 2a). Importantly, $\mathrm{A} \beta$ and $\mathrm{Tg}$ activated JNK to a similar extent, suggesting that $\mathrm{A} \beta$ activates ASK1 and JNK without causing ER stress. Possible involvement of ER stress in $A \beta$-induced ASK1-JNK pathway was further assessed by using primary neurons derived from $\mathrm{E} 14.5$ mice. $\mathrm{A} \beta$ did not induce mRNAs of $\mathrm{BiP}$, also known as GRP78, and CHOP, the other ER stress

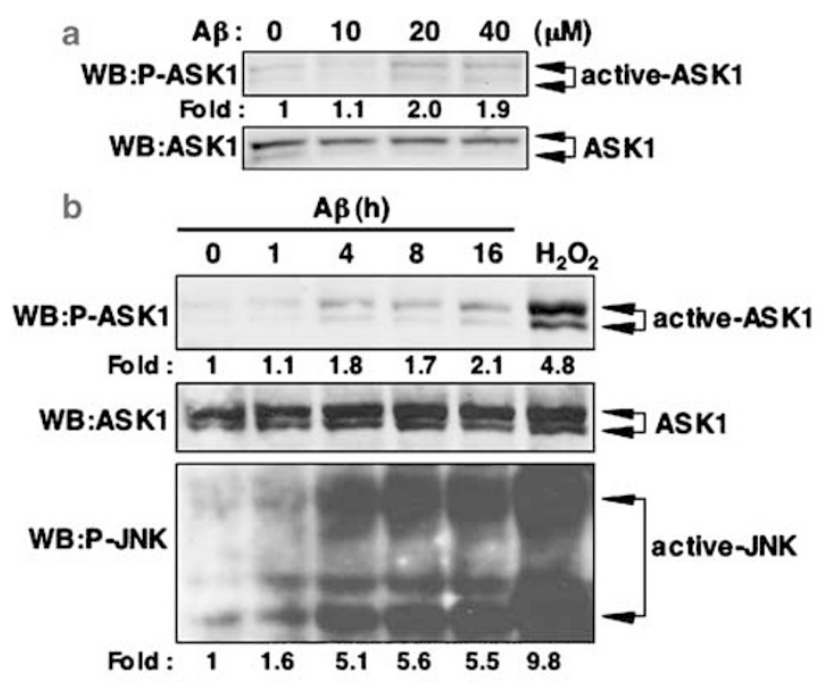

Figure $1 \mathrm{~A} \beta$ activates the ASK1-JNK pathway in PC12 cells. (a) Dosedependent activation of $A S K 1$ by $A \beta$. PC12 cells were treated with $A \beta_{1-42}$ at the indicated dose for $8 \mathrm{~h}$. Cell lysates were subjected to immunoblotting (WB) with antibody to phospho-ASK1 (P-ASK1). The membrane was reprobed with antibody to ASK1 for loading controls. Fold activation of ASK1 is indicated. (b) Time course of $A \beta$-induced ASK1 and JNK activation. PC12 cells were treated with $50 \mu \mathrm{M} \mathrm{A} \beta_{25-35}$ for the indicated time periods or with $1 \mathrm{mM} \mathrm{H}_{2} \mathrm{O}_{2}$ for $30 \mathrm{~min}$. Cell lysates were subjected to WB with antibodies to phospho-ASK1 and phospho-JNK (P-JNK). The membrane was reprobed with antibody to ASK1. Fold activations of ASK1 and JNK are indicated

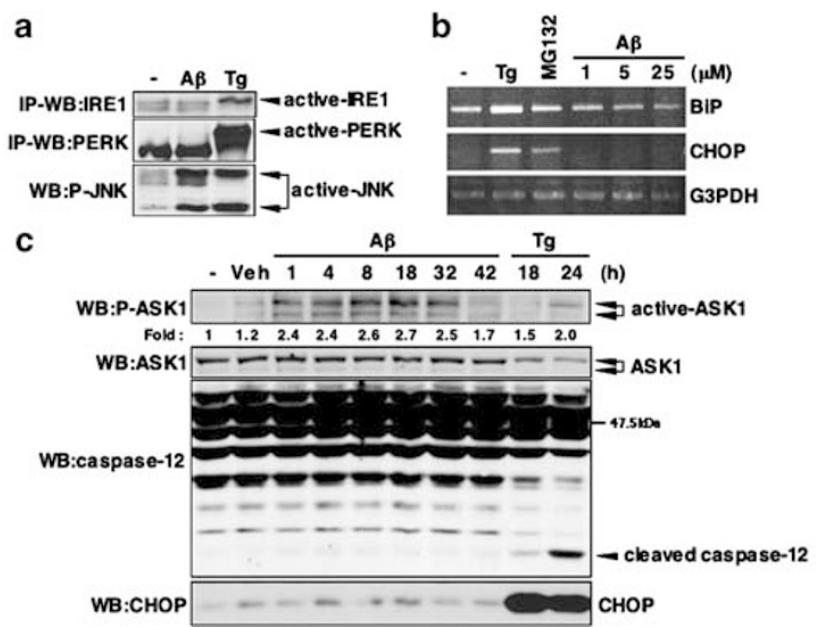

Figure $2 A \beta$ does not induce $E R$ stress. (a) $A \beta$ does not induce activation of endogenous IRE1 and PERK in PC12 cells. PC12 cells were treated with $100 \mu \mathrm{M}$ $\mathrm{A} \beta_{1-42}$ for $16 \mathrm{~h}$ or $20 \mu \mathrm{M} \mathrm{Tg}$ for $30 \mathrm{~min}$. Cells were lysed and analyzed by immunoprecipitation (IP)-immunoblotting (WB) with anti-IRE1 $\alpha$ and anti-PERK antisera. Activation of JNK was confirmed as described in Figure 1b. (b) A $\beta$ does not induce mRNAs of BiP and CHOP in primary neurons. The results of RT-PCR following treatment with $2 \mu \mathrm{M} \mathrm{Tg}$ for $1 \mathrm{~h}, 0.1 \mu \mathrm{M}$ MG132 for $48 \mathrm{~h}$ and the indicated dose of $A \beta_{25-35}$ for $6 \mathrm{~h}$ are shown. Expression of G3PDH was examined as a quantity control (bottom). (c) $A \beta$ does not cleave caspase-12 in PC12 cells. PC12 cells were treated with $40 \mu \mathrm{M} \mathrm{A} \beta_{1-42}$ or $2 \mu \mathrm{M}$ Tg for the indicated time periods. Cell lysates were subjected to WB with antibody to phospho-ASK1. The membrane was reprobed with antibody to ASK1 for loading controls. Fold activation of ASK1 is indicated. Cleavage of caspase-12 was assessed using anti-caspase-12 antiserum. Induction of $\mathrm{CHOP}$ protein was analyzed using anti-CHOP antiserum 
marker (Figure 2b). In contrast, induction of $\mathrm{BiP}$ and $\mathrm{CHOP}$ was clearly observed in these cells by treatment with $\mathrm{Tg}$ or MG132, a proteasome inhibitor that can trigger ER stress through proteasome dysfunction. ${ }^{15}$ These results suggest that $\mathrm{A} \beta$ does not induce ER stress in neuronal cells. Although ER stress is unlikely to be involved in $A \beta$-induced neurotoxicity, caspase-12 might be activated by $\mathrm{A} \beta$ in an ER stressindependent mechanism. Since cleavage is required for $E R$ stress-induced activation of caspase-12, ${ }^{26,27}$ we next analyzed the kinetics of $A \beta$-induced activation of ASK1 and cleavage of caspase-12. Treatment of PC12 cells with $2 \mu \mathrm{M}$ of $\mathrm{Tg}$ for $24 \mathrm{~h}$ induced activation of ASK1 and cleavage of caspase-12 (Figure 2c). A $\beta$-induced activation of ASK1 was also observed within $1 \mathrm{~h}$; however, cleaved caspase-12 was hardly detectable after treatment with $\mathrm{A} \beta$ (Figure $2 \mathrm{c}$ ). Induction of CHOP was also observed by $\mathrm{Tg}$ but not by $\mathrm{A} \beta$ (Figure 2c). These results indicate that induction of ER stress is unlikely to be required for $A \beta$-induced activation of the ASK1-JNK pathway.

\section{ROS mediates A $\beta$-induced ASK1 activation}

Several reports have shown that NO synthesized by NOS participates in the pathogenesis of AD. ${ }^{10,12}$ Since ASK1 has been suggested to be involved in NO-induced death of PC12 cells, ${ }^{28}$ we examined whether $A \beta$-induced ASK1 activation is mediated by NO. Treatment of PC12 cells with NOR1, an NO donor that can spontaneously release $\mathrm{NO}$, strongly activated endogenous ASK1, whereas L-NAME (inhibitor of NO forma-
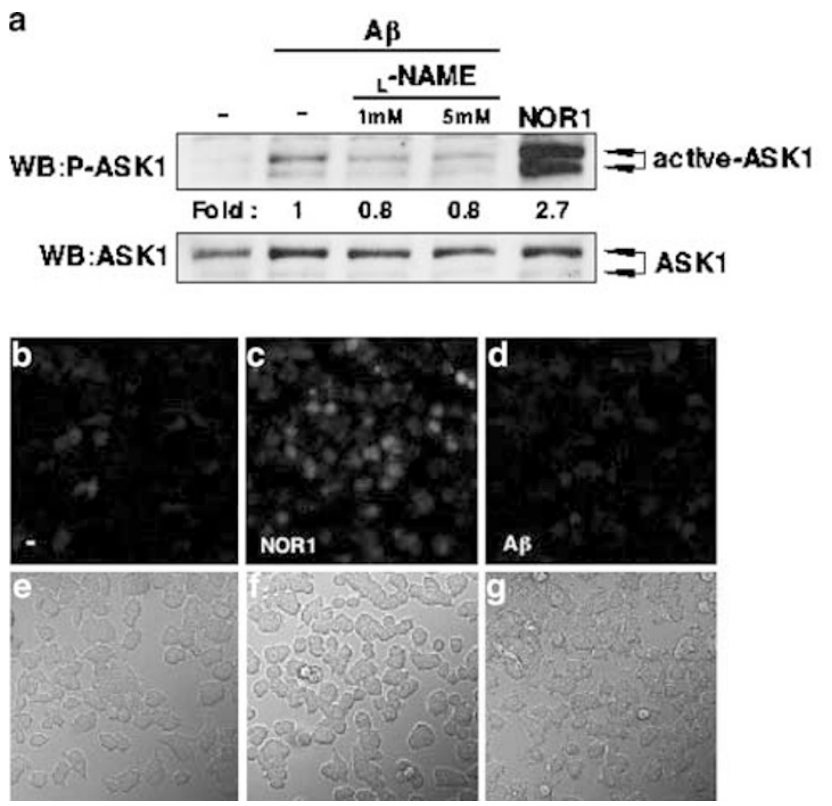

Figure 3 NO-independent activation of ASK1 by A $\beta$. (a) Marginal inhibition of $\mathrm{A} \beta$-induced ASK1 activation by NOS inhibitor. PC12 cells were mixed with 1 or $5 \mathrm{mM} \mathrm{L-NAME}$ for 30 min prior to treatment with $40 \mu \mathrm{M} \mathrm{A} \beta_{1-42}$ for $8 \mathrm{~h}$. PC12 cells were treated with $0.5 \mathrm{mM} \mathrm{NOR} 1$ for $10 \mathrm{~min}$. Fold activation of ASK1 is indicated. $(b-g)$ Fluorescence image of NO in PC12 cells. PC12 cells were stimulated with $0.5 \mathrm{mM}$ NOR1 for $10 \mathrm{~min}(\mathbf{c}, \mathbf{f})$ or treated with $40 \mu \mathrm{M} \mathrm{A} \beta_{1-42}$ for $8 \mathrm{~h}(\mathbf{d}, \mathbf{g})$. Fluorescence images (b-d) of cells were acquired after loading with $100 \mathrm{nM}$ DAF-2 DA for $30 \mathrm{~min}$. Cell morphology was determined by Nomarski differential interference contrast microscopy $(\mathbf{e}-\mathrm{g})$ tion by NOS) had only a marginal effect on A $\beta$-induced ASK1 activation (Figure $3 a$ ). We next examined whether $A \beta$ induces $\mathrm{NO}$ within cells by using a fluorescence probe, DAF-2 DA, that can directly detect NO. ${ }^{29}$ Although $\mathrm{NO}$ was easily detected after treatment with NOR1 (Figure 3c), we could not detect apparent production of NO by treatment with $\mathrm{A} \beta$ (Figure $3 \mathrm{~d}$ ). These results suggest that NOS-induced synthesis of NO may not be the main mechanism for $A \beta$-induced ASK1 activation.

It was reported that ROS is involved in $A \beta$-induced neuronal cell death. ${ }^{7,8}$ Since ASK1 is known to be activated by ROS $^{19}$ and to be required for ROS-induced apoptosis, ${ }^{23}$ we examined whether $\mathrm{A} \beta$-induced ASK1 activation is mediated by ROS. To evaluate the effect of antioxidants on $A \beta$-induced ASK1 activation in PC12 cells, we used three types of antioxidants, propyl gallate (PG; ROS scavenger), MnTBAP (SOD mimetic and peroxynitrite scavenger) and vitamin $E$ (VitE; a physiological membrane-bound antioxidant that protects cell membrane lipids from oxidative damage), each of which has been reported to protect cells from $A \beta$-induced neuronal cell death but by different antioxidant mechanisms. ${ }^{30}$ Each of these anti-oxidants inhibited $\mathrm{H}_{2} \mathrm{O}_{2}$-induced ASK1 activation (Figure 4b). A $\beta$-induced ASK1 activation was strongly inhibited by PG and VitE, and MnTBAP also partially inhibited ASK1 activation (Figure 4a). These results suggest that ROS may be an intermediate of $A \beta$-induced ASK1 activation. We next examined whether $A \beta$ induces ROS within cells by using a fluorescence probe, HPF, that can selectively detect highly reactive oxygen species (hROS) such as hydroxyl radical $(\bullet \mathrm{OH})$ and peroxynitrite $\left(\mathrm{ONOO}^{-}\right) .{ }^{31}$ The fluorescence intensity of PC12 cells was clearly increased after treatment with $\mathrm{H}_{2} \mathrm{O}_{2}$ for 30 min (Figure $4 \mathrm{~d}$ ), and this increase was blocked by PG (Figure 4e), MnTBAP and VitE (data not shown). We could clearly visualize $A \beta$-induced production of ROS (Figure 4f). Fluorescence was abolished in the presence of $P G$, MnTBAP or VitE (Figure $4 g-i)$. These findings indicate that $A \beta$ induces the synthesis of ROS within cells.

\section{ASK1 is required for $A \beta$-induced JNK activation and neuronal cell death}

ASK1 is required for ROS-induced activation of JNK. ${ }^{19,23}$ We assessed the requirement of ASK1 for $A \beta$-induced JNK activation by using a primary neuronal culture derived from E14.5 $A S K 1^{-1-}$ mice. Activation of endogenous JNK by A $\beta$ was lost in $A S K 1^{-1-}$ cells (Figure 5a). Cell death was next determined by $3^{\prime}$-(4,5-dimethyl-2-thiazolyl)-2,5-diphenyl- $2 \mathrm{H}$ tetrazolium bromide (MTT) assay. A $\beta$-induced cell death was observed in about $80 \%$ of $A S K 1^{+/+}$cells (Figure $5 b$ ). $A S K 1^{-1-}$ cells were much less sensitive to the toxic effects of $\mathrm{A} \beta$ than $A S K 1^{+/+}$cells (Figure $5 \mathrm{~b}$ ). Although these cells derived from $A S K 1^{+/+}$and $A S K 1^{-/-}$mice were mixed neuronal and glial cells, more than $90 \%$ of them were positive for microtubuleassociated protein (MAP) 2 (a neuronal marker, data not shown). We may thus conclude that ASK1 is required for $A \beta$ induced JNK activation and neuronal cell death. On the other hand, the partial resistance of $A S K 1^{-1-}$ cells to the $\mathrm{A} \beta$ induced toxicity (Figure $5 \mathrm{~b}$ ) suggests that an ASK1-independent cell death pathway may also exist. Finally, we examined 
a

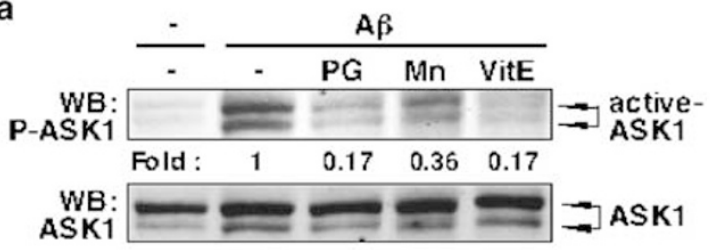

b

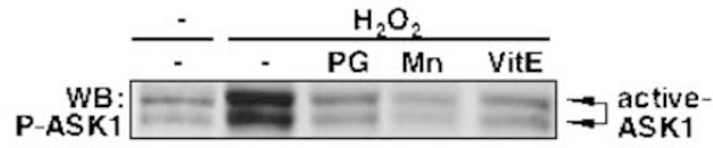

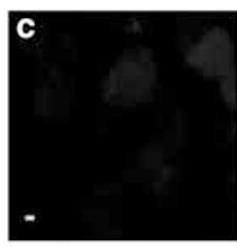
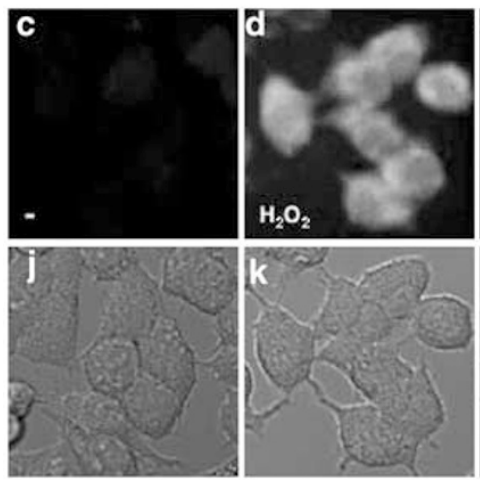
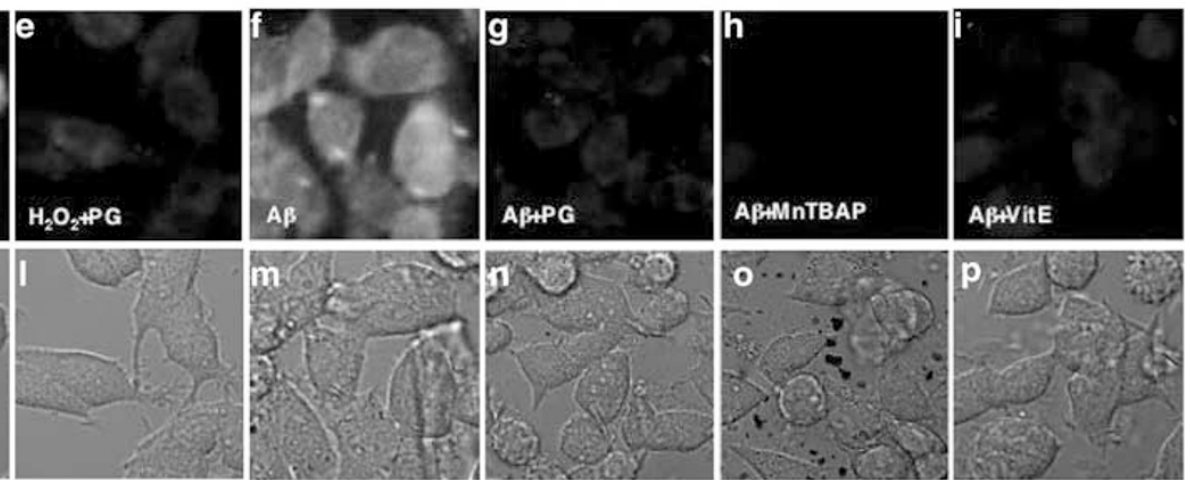

Figure 4 ROS-dependent activation of ASK1 by $A \beta .(\mathbf{a}, \mathbf{b})$ Inhibition of $\mathrm{A} \beta$ - and $\mathrm{H}_{2} \mathrm{O}_{2}$-induced $A S K 1$ activation by antioxidants. PC12 cells were pretreated with antioxidants ( $20 \mu \mathrm{M}$ propyl gallate: PG; $40 \mu \mathrm{M}$ MnTBAP: Mn; $1 \mathrm{mg} / \mathrm{ml}$ vitamin E: VitE) for 30 min prior to treatment with $35 \mu \mathrm{M} \mathrm{A} \beta_{1-42}$ for $8 \mathrm{~h}$ and $1 \mathrm{mM} \mathrm{H} \mathrm{H}_{2}$ for $30 \mathrm{~min}$. Immunoblotting was performed as described in Figure 1a. Fold activation of ASK1 is indicated. (c-p) Fluorescence image of ROS in PC12 cells treated with A $\beta$. PC12 cells were stimulated with $1 \mathrm{mM} \mathrm{H}_{2} \mathrm{O}_{2}$ for 30 min without $(\mathbf{d}, \mathbf{k})$ or with $\mathrm{PG}(\mathbf{e}, \mathbf{l})$, or treated with $40 \mu \mathrm{M} \mathrm{A} \beta_{1-42}$ for $8 \mathrm{~h}$ without $(\mathbf{f}, \mathbf{m})$ or with PG $(\mathbf{g}, \mathbf{n})$, MnTBAP $(\mathbf{h}, \mathbf{0})$ or VitE (i, p). Fluorescence images (c-i) of cells were acquired after loading with $100 \mathrm{nM} \mathrm{HPF}$ for $30 \mathrm{~min}$. Cell morphology was determined by Nomarski differential interference contrast microscopy $(\mathbf{j}-\mathbf{p})$. This experiment was performed three times with similar results

a
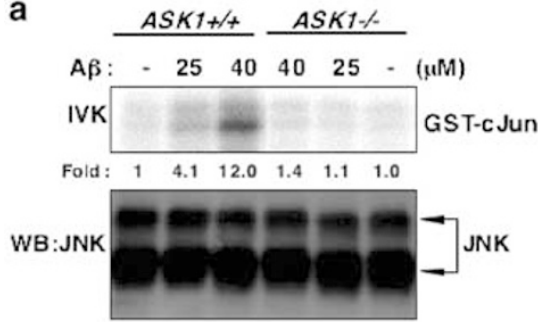

b

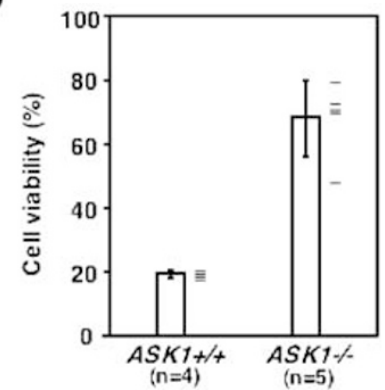

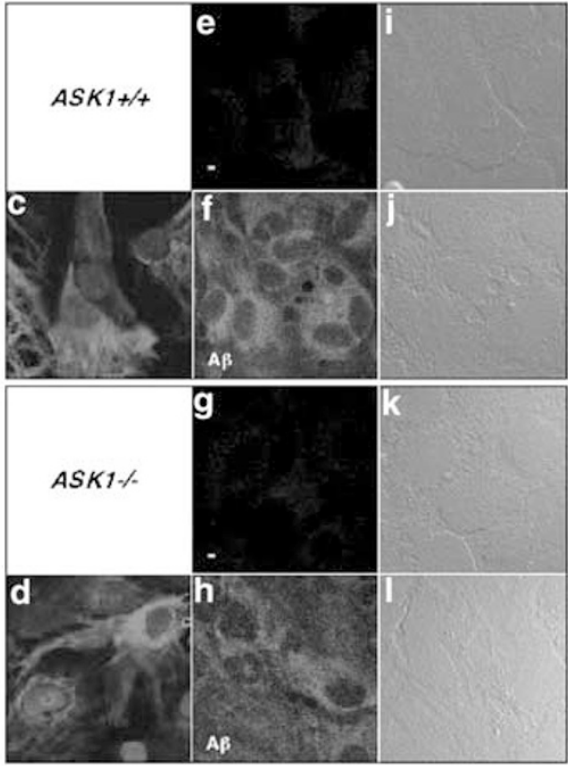

Figure 5 Requirement of ASK1 for A $\beta$-induced JNK activation and cell death. (a) Lack of A $\beta$-induced JNK activation in $A S K 1^{-/-}$neuronal cells. $A S K 1^{+/+}$and $A S K 1^{-1-}$ cells were treated with or without 25 or $40 \mu \mathrm{M} \mathrm{A} \beta_{1-42}$ for $16 \mathrm{~h}$. JNK was immunoprecipitated by anti-JNK antibody and subjected to immune complex kinase assay as described in Materials and Methods. (Top) In vitro kinase assay (IVK) for JNK activity. Expression of JNK (bottom) in the same lysate is shown. Fold activation of JNK is indicated. (b) Lack of $\mathrm{A} \beta$-induced cell death in $A S K 1^{-1-}$ cells. $A S K 1^{+/+}$and $A S K 1^{-1-}$ primary cultured neuronal cells were treated with $25 \mu \mathrm{M} \mathrm{A} \beta_{25-35}$ for 3 days. The graph shows cell viability determined by MTT assay as described in Materials and Methods. Data are means $( \pm S$.E.) of four independent experiments in $A S K 1^{+/+}$and five independent experiments in $A S K 1^{-1-}$ derived from independent embryos. (c-l) Fluorescence images of ROS in $A S K 1^{+/+}$and $A S K 1^{-1-}$ astrocytes treated with $\mathrm{A} \beta . A S K 1^{+/+}$(c) and $A S K 1^{-/-}$(d) astrocytes were stained with anti-GFAP antibody and Hoechst $33258 . A S K 1^{+/+}(\mathbf{e}, \mathbf{f}, \mathbf{i}, \mathbf{j})$ and $A S K 1^{-/-}(\mathbf{g}, \mathbf{h}, \mathbf{k}, \mathbf{l})$ primary astrocytes were treated without $(\mathbf{e}, \mathbf{i}, \mathbf{g}, \mathbf{k})$ or with $40 \mu \mathrm{M} \mathrm{A} \beta_{1-42}$ for $4 \mathrm{~h}(\mathbf{f}, \mathbf{j}, \mathbf{h}, \mathbf{l})$. Fluorescence images $(\mathbf{e}-\mathbf{h})$ of cells were acquired as described in Figure 4 . Cell morphology was determined by Nomarski differential interference contrast microscopy $(\mathrm{i}-\mathrm{l})$. The experiment was performed three times with similar results 
the effect of ASK1 deficiency on $A \beta$-induced production of ROS. Due to the nonspecific high background of ROS in the primary neuronal culture, we examined $\mathrm{A} \beta$-induced production of ROS in $A S K 1^{+/+}$and $A S K 1^{-1-}$ primary astrocytes, which were positive for glial fibrillary acidic protein (GFAP) (Figure $5 \mathrm{c}$ and $\mathrm{d}$ ). $\mathrm{A} \beta$-induced production of ROS was indistinguishable between $A S K 1^{+/+}$and $A S K 1^{-/-}$astrocytes (Figure $5 \mathrm{f}$ and $\mathrm{h}$ ). These results suggest that synthesis of ROS by $\mathrm{A} \beta$ does not require ASK1.

The accumulation of $A \beta$ peptides to form fibrillar deposits is closely related to the loss of neuronal cells in AD. Pathologic and biochemical studies suggest that ROS synthesized by fibrillar $\mathrm{A} \beta$ has neurotoxic effects. ${ }^{32,33}$ Recent studies suggested that monomeric (soluble) $\mathrm{A} \beta$ acts as a natural antioxidant that prevents neuronal cell death caused by oxidative stress, whereas fibrillar $A \beta$ is an ROS generator and neurotoxic. ${ }^{34}$ Gly33 and Met35 of $\mathrm{A} \beta_{1-42}$ peptide have been reported to be essential for ROS production and neurotoxicity. ${ }^{35}$ However, the precise molecular mechanism by which $\mathrm{A} \beta$ leads to neuronal cell death has not been elucidated. In this study, we have shown for the first time that $A \beta$ targets the ASK1-JNK proapoptotic pathway through ROS production. Since the molecular mechanism of $A \beta$-induced production of ROS has not been elucidated, the identification of the target molecules of $A \beta$ for the synthesis of ROS should shed light on the regulation of $A \beta$-induced neuronal cell death.

In conclusion, the results presented here strongly suggest that ROS-induced ASK1 activation by $\mathrm{A} \beta$ is an important step in the pathogenesis of AD. ASK1 may thus be a therapeutic target for prevention and treatment of $A D$.

\section{Materials and Methods}

\section{Cell cultures}

PC12 cells and primary neurons were maintained as described. ${ }^{15}$ For primary astroglial cultures, telencepharons from neonatal C57BL/6 mice were minced into small pieces with a scalpel in Hank's balanced salt solution (HBSS), and treated with HBSS containing $0.25 \%$ trypsin and $0.1 \%$ DNase I for $15 \mathrm{~min}$ at $37^{\circ} \mathrm{C}$. Dissociated cells were cultured in MEM with Earle's supplemented with 10\% FBS and penicillin G $(100 \mathrm{U} / \mathrm{ml})$ containing $30 \mathrm{mM}$ glucose. The purity of astrocytes was assessed by immunofluorescent staining for anti-GFAP antibody (DAKO).

\section{Reagents}

$\mathrm{A} \beta_{25-35}$ and $\mathrm{A} \beta_{1-42}$ were purchased from Bachem and American Peptide Company, respectively. $\mathrm{A} \beta_{25-35}$ was dissolved in water at $1 \mathrm{mM}$ and $\mathrm{A} \beta_{1-42}$ was dissolved in water containing $0.1 \% \mathrm{NH}_{3}$ at $1 \mathrm{mM}$. Dissolved $\mathrm{A} \beta$ peptides were mixed with the same volume of PBS and incubated at $37^{\circ} \mathrm{C}$ for $3-5$ days before use. PG, MnTBAP and VitE were purchased from Calbiochem.

\section{Western blot analysis}

Cells were lysed on ice in a lysis buffer containing $20 \mathrm{mM}$ Tris- $\mathrm{HCl}(\mathrm{pH}$ 7.5), $150 \mathrm{mM} \mathrm{NaCl}, 10 \mathrm{mM}$ EDTA (pH 7.5), $1 \%$ Triton X-100 and $1 \%$ deoxycholate, and cell extracts were clarified by centrifugation, resolved on SDS-PAGE and transferred onto PVDF membranes. After blocking with $5 \%$ skim milk in TBS-T (50 mM Tris- $\mathrm{HCl}(\mathrm{pH} 8.0), 150 \mathrm{mM} \mathrm{NaCl}$ and
$0.05 \%$ Tween 20 ), the membranes were probed with antibodies to ASK1, phospho-ASK1, JNK, phospho-JNK, CHOP and caspase-12. Blots were developed with ECL (Amersham). The amount of protein was quantified by $\mathrm{NIH}$ Image.

\section{RT-PCR, immunoblotting and band-shift analysis for IRE1 and PERK}

RT-PCR, immunoblotting and band-shift analysis for IRE1 and PERK have been described. ${ }^{15}$

\section{Bioimaging of $\mathrm{NO}$ and ROS}

PC12 cells and astrocytes were seeded onto a glass-bottomed dish. For detection of NO, the cells were mixed with $100 \mathrm{nM} \mathrm{DAF}-2 \mathrm{DA}^{29}$ for $1 \mathrm{~h}$ after treatment with $A \beta$ for $8 \mathrm{~h}$ or before treatment with $0.5 \mathrm{mM}$ NOR1 for $10 \mathrm{~min}$. Fluorescence images were acquired after washing with medium. For the detection of ROS, the cells were mixed with $100 \mathrm{nM} \mathrm{HPF}$ after incubation with $\mathrm{A} \beta$ for $8 \mathrm{~h}$ or with $\mathrm{H}_{2} \mathrm{O}_{2}$ for $30 \mathrm{~min}$ in the presence or absence of antioxidants. After $30 \mathrm{~min}$ of incubation at $37^{\circ} \mathrm{C}$, fluorescence images were acquired using an LSM510 confocal laser scanning unit coupled to an Axiovert 100M inverted microscope with a C Apochromat $\times 40 / 1.2$ objective lens (Carl Zeiss). The excitation wavelength was $488 \mathrm{~nm}$, and the emission was filtered using a $505-530 \mathrm{~nm}$ barrier filter.

\section{Immune complex kinase assay for JNK}

Primary neurons $\left(3 \times 10^{6}\right)$ in six-well plates were lysed with the lysis buffer and immunoprecipitated with anti-JNK polyclonal antibody (Santa Cruz). The kinase assay using GST-cJun (1-79) has been described. ${ }^{20}$ The amount of JNK protein was determined by immunoblotting with anti-JNK polyclonal antibody.

\section{MTT assay}

Viability of primary neurons was determined as described. ${ }^{15}$ The relative number of surviving cells was determined in triplicate using the value for cells stimulated with vehicles as $100 \%$.

\section{Acknowledgements}

We thank $Y$ Gotoh for the protocol for $A \beta$ solubilization. We also thank all the members of the Cell Signaling Laboratory for their critical comments. This study was supported by Grants-in-Aid for scientific research and Center of Excellence grants from the Ministry of Education, Culture, Sports, Science and Technology of Japan.

\section{References}

1. Selkoe DJ (1999) Translating cell biology into therapeutic advances in Alzheimer's disease. Nature 399: A23-A31

2. Yankner BA (1996) Mechanisms of neuronal degeneration in Alzheimer's disease. Neuron 16: 921-932

3. Selkoe DJ (2001) Alzheimer's disease results from the cerebral accumulation and cytotoxicity of amyloid $\beta$-protein. J. Alzheimers Dis. 3: 75-80

4. Stadelmann C, Deckwerth TL, Srinivasan A, Bancher C, Bruck W, Jellinger $K$ and Lassmann H (1999) Activation of caspase-3 in single neurons and autophagic granules of granulovacuolar degeneration in Alzheimer's disease. Evidence for apoptotic cell death. Am. J. Pathol. 155: 1459-1466 
5. Hensley K, Carney JM, Mattson MP, Aksenova M, Harris M, Wu JF, Floyd RA and Butterfield DA (1994) A model for $\beta$-amyloid aggregation and neurotoxicity based on free radical generation by the peptide: relevance to Alzheimer disease. Proc. Natl. Acad. Sci. USA 91: 3270-3274

6. Shearman MS, Ragan Cl and Iversen LL (1994) Inhibition of PC12 cell redox activity is a specific, early indicator of the mechanism of $\beta$-amyloid-mediated cell death. Proc. Natl. Acad. Sci. USA 91: 1470-1474

7. Behl C, Davis JB, Lesley R and Schubert D (1994) Hydrogen peroxide mediates amyloid $\beta$-protein toxicity. Cell $77: 817-827$

8. Mattson MP and Goodman Y (1995) Different amyloidogenic peptides share a similar mechanism of neurotoxicity involving reactive oxygen species and calcium. Brain Res. 676: 219-224

9. Pillot T, Drouet B, Queille S, Labeur C, Vandekerchkhove J, Rosseneu M, Pincon-Raymond M and Chambaz J (1999) The nonfibrillar amyloid $\beta$-peptide induces apoptotic neuronal cell death: involvement of its $\mathrm{C}$-terminal fusogenic domain. J. Neurochem. 73: 1626-1634

10. Vodovotz Y, Lucia MS, Flanders KC, Chesler L, Xie QW, Smith TW, Weidner J, Mumford R, Webber R, Nathan C, Roberts AB, Lippa CF and Sporn MB (1996) Inducible nitric oxide synthase in tangle-bearing neurons of patients with Alzheimer's disease. J. Exp. Med. 184: 1425-1433

11. Good PF, Werner P, Hsu A, Olanow CW and Perl DP (1996) Evidence of neuronal oxidative damage in Alzheimer's disease. Am. J. Pathol. 149: 21-28

12. Hashimoto $Y$, Ito $Y$, Arakawa E, Kita $Y$, Terashita K, Niikura T and Nishimoto I (2002) Neurotoxic mechanisms triggered by Alzheimer's disease-linked mutant M146L presenilin 1: involvement of NO synthase via a novel pertussis toxin target. J. Neurochem. 80: 426-437

13. Nakagawa T, Zhu H, Morishima N, Li E, Xu J, Yankner BA and Yuan J (2000) Caspase-12 mediates endoplasmic-reticulum-specific apoptosis and cytotoxicity by amyloid- $\beta$. Nature 403: 98-103

14. Imai $Y$, Soda M, Inoue H, Hattori N, Mizuno Y and Takahashi R (2001) An unfolded putative transmembrane polypeptide, which can lead to endoplasmic reticulum stress, is a substrate of Parkin. Cell 105: 891-902

15. Nishitoh H, Matsuzawa A, Tobiume K, Saegusa K, Takeda K, Inoue K, Hori S, Kakizuka A and Ichijo $\mathrm{H}$ (2002) ASK1 is essential for endoplasmic reticulum stress-induced neuronal cell death triggered by expanded polyglutamine repeats. Genes Dev. 16: 1345-1355

16. Morishima Y, Gotoh Y, Zieg J, Barrett T, Takano H, Flavell R, Davis RJ, Shirasaki $Y$ and Greenberg ME (2001) $\beta$-amyloid induces neuronal apoptosis via a mechanism that involves the c-Jun $\mathrm{N}$-terminal kinase pathway and the induction of Fas ligand. J. Neurosci. 21: 7551-7560

17. Song S, Kim SY, Hong YM, Jo DG, Lee JY, Shim SM, Chung CW, Seo SJ, Yoo YJ, Koh JY, Lee MC, Yates AJ, Ichijo H and Jung YK (2003) Essential role of E2-25K/Hip-2 in mediating amyloid- $\beta$ neurotoxicity. Mol. Cell 12: 553-563

18. Kihiko ME, Tucker HM, Rydel RE and Estus S (1999) c-Jun contributes to amyloid $\beta$-induced neuronal apoptosis but is not necessary for amyloid $\beta$ induced c-jun induction. J. Neurochem. 73: 2609-2612

19. Saitoh M, Nishitoh H, Fujii M, Takeda K, Tobiume K, Sawada Y, Kawabata M, Miyazono K and Ichijo H (1998) Mammalian thioredoxin is a direct inhibitor of apoptosis signal-regulating kinase (ASK) 1. EMBO J. 17: 2596-2606

20. Nishitoh H, Saitoh M, Mochida Y, Takeda K, Nakano H, Rothe M, Miyazono K and Ichijo H (1998) ASK1 is essential for JNK/SAPK activation by TRAF2. Mol. Cell 2: 389-395

21. Ichijo $H$, Nishida $E$, Irie $K$, ten Dijke $P$, Saitoh $M$, Moriguchi T, Takagi M, Matsumoto K, Miyazono K and Gotoh Y (1997) Induction of apoptosis by ASK1, a mammalian MAPKKK that activates SAPK/JNK and p38 signaling pathways. Science 275: 90-94

22. Hatai T, Matsuzawa A, Inoshita S, Mochida Y, Kuroda T, Sakamaki K, Kuida K, Yonehara S, Ichijo H and Takeda K (2000) Execution of apoptosis signalregulating kinase 1 (ASK1)-induced apoptosis by the mitochondria-dependent caspase activation. J. Biol. Chem. 275: 26576-26581

23. Tobiume K, Matsuzawa A, Takahashi T, Nishitoh H, Morita K, Takeda K, Minowa O, Miyazono K, Noda T and Ichijo H (2001) ASK1 is required for sustained activations of JNK/p38 MAP kinases and apoptosis. EMBO Rep. 2 222-228

24. Tobiume K, Saitoh M and Ichijo H (2002) Activation of apoptosis signalregulating kinase 1 by the stress-induced activating phosphorylation of preformed oligomer. J. Cell. Physiol. 191: 95-104

25. Imaizumi K, Miyoshi K, Katayama T, Yoneda T, Taniguchi M, Kudo T and Tohyama M (2001) The unfolded protein response and Alzheimer's disease. Biochim. Biophys. Acta 1536: 85-96

26. Nakagawa $T$ and Yuan J (2000) Cross-talk between two cysteine protease families. Activation of caspase-12 by calpain in apoptosis. J. Cell Biol. 150: 887-894

27. Fujita $E$, Kouroku $Y$, Jimbo A, Isoai $A$, Maruyama $K$ and Momoi $T$ (2002) Caspase-12 processing and fragment translocation into nuclei of tunicamycintreated cells. Cell Death Differ. 9: 1108-1114

28. Han OJ, Joe KH, Kim SW, Lee HS, Kwon NS, Baek KJ and Yun HY (2001) Involvement of p38 mitogen-activated protein kinase and apoptosis signalregulating kinase-1 in nitric oxide-induced cell death in $\mathrm{PC} 12$ cells. Neurochem. Res. 26: 525-532

29. Kojima $\mathrm{H}$, Nakatsubo $\mathrm{N}$, Kikuchi $\mathrm{K}$, Kawahara $\mathrm{S}$, Kirino $\mathrm{Y}$, Nagoshi $\mathrm{H}$, Hirata $Y$ and Nagano T (1998) Detection and imaging of nitric oxide with novel fluorescent indicators: diaminofluoresceins. Anal. Chem. 70: 24462453

30. Kruman I, Bruce-Keller AJ, Bredesen D, Waeg G and Mattson MP (1997) Evidence that 4-hydroxynonenal mediates oxidative stress-induced neuronal apoptosis. J. Neurosci. 17: 5089-5100

31. Setsukinai K, Urano Y, Kakinuma K, Majima HJ and Nagano T (2003) Development of novel fluorescence probes that can reliably detect reactive oxygen species and distinguish specific species. J. Biol. Chem. 278: 3170-3175

32. Gervais FG, Xu D, Robertson GS, Vaillancourt JP, Zhu Y, Huang J, LeBlanc A, Smith D, Rigby M, Shearman MS, Clarke EE, Zheng H, Van Der Ploeg LH, Ruffolo SC, Thornberry NA, Xanthoudakis S, Zamboni RJ, Roy S and Nicholson DW (1999) Involvement of caspases in proteolytic cleavage of Alzheimer's amyloid- $\beta$ precursor protein and amyloidogenic A $\beta$-peptide formation. Cell 97: 395-406

33. Savory J, Rao JK, Huang Y, Letada PR and Herman MM (1999) Age-related hippocampal changes in $\mathrm{Bcl}-2$ : Bax ratio, oxidative stress, redox-active iron and apoptosis associated with aluminum-induced neurodegeneration: increased susceptibility with aging. Neurotoxicology 20: 805-817

34. Zou K, Gong JS, Yanagisawa K and Michikawa M (2002) A novel function of monomeric amyloid $\beta$-protein serving as an antioxidant molecule against metalinduced oxidative damage. J. Neurosci. 22: 4833-4841

35. Kanski J, Varadarajan S, Aksenova M and Butterfield DA (2002) Role of glycine-33 and methionine-35 in Alzheimer's amyloid $\beta$-peptide 1-42associated oxidative stress and neurotoxicity. Biochim. Biophys. Acta 1586: 190-198 